\title{
Interatrial communication
}

INSERM

\section{Source}

INSERM. (1999). Orphanet: an online rare disease and orphan drug data base. Interatrial communication. ORPHA:1478

Interauricular communication is a congenital malformation characterized by a communication between the atrial chambers of the heart. 